\title{
Obstruction of the fetal urinary tract: a role for surgical intervention in utero?
}

\author{
I R McFADYEN
}

\begin{abstract}
Obstruction of the lower urinary tract was diagnosed by ultrasound in 11 fetuses. One pregnancy was therapeutically aborted. Four of the neonates died within 48 hours because of pronounced pulmonary hypoplasia, which is associated with obstruction of the urinary tract. The remaining six survived with adequate renal function but one, now aged 4, is obviously too small for his age.

Intervention in utero for obstruction of the urinary tract is safe, but those fetuses for whom it is appropriate cannot yet be identified because of difficulties in diagnosing the condition of the whole fetus.
\end{abstract}

\section{Introduction \\ Congenital abnormalities of the urinary tract occur once in every 740-3000 deliveries. ${ }^{1}$ " Active intervention before delivery to relieve obstruction of the urinary tract in the fetus has become practicable only in the past few years. Two techno- logical advances have made this possible: development of ultrasound to allow precision in localising the site and extent of the obstruction, ${ }^{3}$ and methods (developed in research on animals) for maintaining catheters in fetuses. ${ }^{45}$ Intervention is now possible, but is it indicated? The obstructed urinary tracts of three fetuses were drained at Northwick Park Hospital, and details have been published of eight others treated in this way. This review of these 11 fetuses and of others who were not treated shows the problems that exist in diagnosing accurately the condition of the whole fetus, in making decisions about which fetus should be treated, and in assessing the results of treatment.}

Division of Perinatal Medicine, MRC Clinical Research Centre, Harrow HA1 3UJ, Middlesex

I R MCFADYEN, FRCOG, consultant obstetrician and gynaecologist

\section{Physiopathology}

Obstruction of the fetal urinary tract may be caused by urethral valves, urethral agenesis, and similar lesions or there may be no obvious anatomical abnormality. ${ }^{6} 7$ Whatever the cause there is hypertrophy of the bladder and distension of the collecting system above it. As little or no urine is being excreted by most of these fetuses the amniotic fluid is usually scanty; occasionally, however, urine may leak through the urachus ${ }^{7}$ or urethral valves may allow small quantities of urine to pass into the amniotic cavity with the formation of liquor. Occasionally the obstruction appears to resolve spontaneously. ${ }^{8}$ If obstruction is complete before mid-pregnancy irremediable abnormalities of renal development are likely because division of the metanephric ampulla, which forms the urinary collecting system, slows by 13-14 weeks and ceases by about 20 weeks. Obstruction which is incomplete or occurs later in pregnancy does not interfere with tubular growth, but it may affect the development of nephrons as this continues until 34-36 weeks. Back pressure affects renal function as well as renal development. This may not become obvious until after delivery as the placenta manages fetal homoeostatis; but once the child is delivered it may not be able to survive because the kidneys are severely damaged.

Renal function affects fetal growth. Anephric lambs and humans are born lighter than those with kidneys. ${ }^{6} 9$ Impaired renal function slows fetal growth, and the earlier in life damage to the kidney occurs the more is growth impaired. ${ }^{10}$ Severe obstruction of the renal tract diagnosed within one month of birth is associated with stature remaining below the 25th centile permanently and the weight below the 35 th centile, but less severe disease which becomes apparent later in life does not impair development so substantially. ${ }^{11}$ Some fetuses with obstruction of the urinary tract certainly are born light for dates, and growth is likely to remain impaired in the survivors.

Impaired fetal growth with obstruction of the urinary tract may sometimes be caused by anomalies in other systems. 
Defects of the gastrointestinal and central nervous system are common; defects of the abdominal wall muscle and cryptorchidism not infrequently accompany obstruction of the urinary tract ("prune belly syndrome"), and these fetuses also tend to have other congenital defects. ${ }^{6}$ ? Chromosomal anomalies may be associated with urinary obstruction, which occurs in at least half of those with Edwards's syndrome (trisomy 18).13 Though oligohydramnios is associated with failure of fetal micturition and may produce compression of the fetus or other problems, it does not slow fetal growth. ${ }^{14}$

Survival after delivery is as likely to be determined by pulmonary as by renal function. Hypoplasia of the lungs occurs with fetal urinary obstruction as well as with renal agenesis and spontaneous rupture of the membranes before 20 weeks. Normal development of the lung requires secretion of liquid and its retention within the airways. ${ }^{15}$ Oligohydramnios and increased intra-abdominal pressure both tend to prevent retention of fluid within the lungs which, therefore, do not develop normally. Not only are they anatomically hypoplastic but the respiratory epithelium is not sufficiently developed to produce surfactant. ${ }^{16} 17$ Many of these babies die within a few hours of birth because their lungs cannot respire effectively, before renal insufficiency produces any problems (tables I and II).

\section{Diagnosis}

Ultrasound is the only satisfactory and effective non-invasive method of diagnosis. It defines the level of obstruction and degree of distension of the urinary tract. With accumulated experience cystic dysplasia can be detected in most fetuses in which it occurs. The amount of amniotic fluid present can be assessed, and fetal diuresis in response to a diuretic given to the mother may show that there is some active renal tissue. ${ }^{18}$ The absence of a fetal bladder on repeated scans in which kidneys are seen suggests severe renal disease, ${ }^{18}$ and slowing of fetal growth may indicate deteriorating fetal renal function. ${ }^{12}$ In most cases, however, renal function cannot be assessed without catheterisation of the obstructed urinary tract, and there are few criteria to help judge normality of function in the human fetus at the gestational ages when this might be used to plan management. Injection of radio-opaque materials into the bladder has been used to help localisation of the obstructive lesion and to determine whether or not urine was passing into the amniotic sac. ${ }^{12} 19$

Pulmonary development cannot be assessed before delivery without a sample of amniotic fluid. Fetal breathing movements are not helpful as they may be seen with both normal and hypoplastic lungs, ${ }^{12}{ }^{20}$ nor do hypoplastic lungs have a typical appearance on ultrasound, but the volume of the chest may be reduced if the development of the lungs is retarded. ${ }^{19}$ Some skeletal and some soft tissue congenital anomalies can be diagnosed by ultrasound, but many cannot. Chromosomal anomalies, which require specimens of tissue or of urine for their identification, are probably the most important of these.

\section{Treatment}

Intervention is unnecessary in some cases; in others it is of no value or may be contraindicated. It is usually unnecessary when the obstruction is known to be ureteric and unilateral as the other kidney generally has normal function. ${ }^{18}$ In one fetus with unilateral obstruction a catheter was inserted to preserve that kidney's function, ${ }^{21}$ and drainage certainly is necessary if an obstructed hydronephrotic kidney compresses the other side of the urinary tract. ${ }^{22}$ Treatment would be contraindicated if the kidneys could be seen but the bladder could not as this indicates that renal damage is severe. ${ }^{18}$ If the fetus is found to have another substantial anomaly it is unlikely that many would advise intervention or that parents would wish it. The prune belly syndrome, biliary atresia, microcolon, and meconium ileus were present in some of these fetuses with obstruction of the urinary tract; none had a lethal abnormality but one has Larsen's syndrome, though none of the others has a chromosomal aberration. Few anomalies can be diagnosed in utero, but if they are known to be present they unavoidably affect decisions regarding treatment.

The object of treatment before delivery is to limit renal

TABLE I-Details of seven cases of urinary tract obstruction diagnosed at Northwick Park Hospital $1979-83$ from about 16500 deliveries. No other cases were diagnosed in first week of life. Birth weight centiles calculated from data of Thomson et al $1968^{30}$

\begin{tabular}{|c|c|c|c|c|c|c|}
\hline Case No & $\begin{array}{c}\text { Diagnosed } \\
\text { (weeks) }\end{array}$ & $\begin{array}{r}\text { Inter } \\
\text { When (weeks) }\end{array}$ & $\begin{array}{l}\text { ntion } \\
\text { How }\end{array}$ & $\begin{array}{c}\text { Delivered } \\
\text { (weeks) }\end{array}$ & $\begin{array}{l}\text { Birth weight } \\
\text { (g) }(\%)\end{array}$ & Outcome \\
\hline $\begin{array}{l}1 \\
2 \\
3\end{array}$ & $\begin{array}{l}16 \\
34 \\
25\end{array}$ & \multirow[t]{5}{*}{$\begin{array}{l}16 \\
35-37 \\
26-27\end{array}$} & \multirow[t]{5}{*}{$\begin{array}{l}\text { Single tap } \\
\text { Catheter } \\
\text { Catheter }\end{array}$} & $\begin{array}{l}17 \\
37 \\
35\end{array}$ & \multirow{5}{*}{$\begin{array}{l}1480(<1) \\
2160(15) \\
2460(10) \\
\left\{\begin{array}{l}2300(30) \\
2100(15) \\
3420(60) \\
4800(99)\end{array}\right.\end{array}$} & \multirow{5}{*}{$\begin{array}{l}\text { Urethral hypoplasia, lung hypoplasia, prune belly syndrome } \\
\text { Alive at } 4 \text { years, growth retarded } \\
\text { Died aged } 2 \text { days, obstructed posterior urethra; hypoplastic lungs; renal } \\
\text { cystic dysplasia } \\
\text { Died aged } 1 \text { month, multicystic right kidney, hydronephrotic left kidney } \\
\text { no obvious urethral obstruction } \\
\text { Alive at } 18 \text { weeks, polyhydraminios, undescended testicles; pulmonary } \\
\text { hypoplasia; renal dysplasia } \\
\text { Healthy twin: alive } \\
\text { Alive, aged } 4 \text {, Larsen's syndrome, well; recurrent urinary infections; } \\
\text { bilateral hydronephrosis ureteric reflux; no urethral obstruction } \\
\text { Alive, aged 3, left ureteric obstruction only }\end{array}$} \\
\hline 4 & 27 & & & 35 & & \\
\hline 5 & 30 & & & 34 & & \\
\hline 6 & 37 & & & 37 & & \\
\hline 7 & 38 & & & 39 & & \\
\hline
\end{tabular}

TABLE II-Details of published interventions for obstruction of the fetal urinary tract. Birth weight centiles calculated from data of Thomson et al $1968^{30}$

\begin{tabular}{|c|c|c|c|c|c|c|}
\hline & $\underset{\text { (weeks) }}{\text { Diagnosed }}$ & $\begin{array}{r}\text { Inter } \\
\text { When (weeks) }\end{array}$ & How & $\begin{array}{l}\text { Delivered } \\
\text { (weeks) }\end{array}$ & $\begin{array}{l}\text { Birth weight } \\
\quad(\mathrm{g})(\%)\end{array}$ & Outcome \\
\hline Harrison et al $1982^{25}$ & 20 & $21-35$ & $\begin{array}{l}\text { Bilateral } \\
\text { ureterostomy }\end{array}$ & 35 & $2200(20)$ & Died; urethral valves pulmonary hypoplasia renal dysplasia \\
\hline Golbus et al $1982^{23}$ & 23 & 32 & $\begin{array}{l}\text { Bladder-amniotic } \\
\text { shunt }\end{array}$ & 34 & $\left\{\begin{array}{l}2080(20) \\
2300(60)\end{array}\right.$ & $\begin{array}{l}\text { Prune belly syndrome, intestinal malrotation, mild renal dysplasia, } \\
\text { normal lungs; alive } \\
\text { Healthy twin }\end{array}$ \\
\hline Berkowitz et al $1982^{20}$ & 23 & 24 & $\begin{array}{l}\text { Bladder-amniotic } \\
\text { shunt }\end{array}$ & 32 & $2470(90)$ & Died; urethral values, pulmonary hypoplasia, renal dysplasia \\
\hline Gadziala et al $1982^{24}$ & 21 & 27 & Single tap & 37 & $3140(50)$ & $\begin{array}{l}\text { Prune belly; normal pulmonary and renal function, biliary } \\
\text { atresia, well at } 6 \text { months }\end{array}$ \\
\hline Manning et al $1983^{\circ}$ & 14 & 16 & $\begin{array}{l}\text { Bladder-amniotic } \\
\text { shunt }\end{array}$ & 35 & $2300(20)$ & Normal pulmonary and renal function; well at 6 months \\
\hline Manning et al $1983^{10}$ & 16 & 16 & $\begin{array}{l}\text { Bladder-amniotic } \\
\text { shunt }\end{array}$ & 30 & $1650(-)$ & $\begin{array}{l}\text { Died; bladder neck obstruction; pulmonary hypoplasia, bilateral } \\
\text { hydroureter and hydronephrosis }\end{array}$ \\
\hline $\begin{array}{l}\text { Vintzileos et al } 1983^{21} \\
\text { Schapps et al } 1983^{21}\end{array}$ & 29 & $32-34$ & $\begin{array}{l}\text { Single tap } \\
\text { Bladder-amniotic } \\
\text { shunt }\end{array}$ & $\begin{array}{l}35 \\
34\end{array}$ & $\begin{array}{l}2800(60) \\
2340(37)\end{array}$ & $\begin{array}{l}\text { Pyeloplasty, well } \\
\text { Prune belly, nephrectomy well }\end{array}$ \\
\hline
\end{tabular}


damage thus allowing time for the other systems to develop and making survival more likely; it also helps to retain some potential for "catch up" development after delivery. ${ }^{12}{ }^{23}$

Drainage of the dilated urinary tract may be achieved in different ways. Firstly, a catheter may be passed from the dilated urinary tract into the amniotic cavity. ${ }^{20}{ }^{23}$ This is the most physiological method and reduces the possibility of infection, but it presents technical problems if there is oligohydramnios. The amniotic cavity may be enlarged by introducing saline, which will simplify introduction of the catheter. ${ }^{20}$ If sufficient amniotic fluid is already present to allow such catheters to be inserted without difficulty, is the procedure necessary? Urethral valves may produce sufficient back pressure to prevent normal renal development yet allow the formation of amniotic fluid, suggesting that bladder drainage may be of value in such cases. It is also possible that reduction of intravesical pressure allows passage of urine past valves that are obstructive when the bladder is overfilled. ${ }^{12}$

Secondly, a catheter may be passed through the maternal abdomen draining externally. ${ }^{12}$ Though technically straightforward such continuous drainage may introduce infection, but the advantage is that urinary output may be measured and renal function assessed.

Thirdly, a single puncture to relieve pressure within the urinary tract will allow leakage of urine into the fetal peritoneal cavity, ${ }^{12} 24$ but this has not been used as an elective route of drainage.

Finally, ureterostomy has been used in one case. ${ }^{25}$ This is the most traumatic treatment and should be used only if other methods are not practicable.

When drainage has been established the next decision is for how long it should continue. In most cases this has not been a problem as premature labour has started spontaneously or delivery has been required for a maternal indication, though blockage of the catheter has been a reason for elective delivery.

\section{Results of treatment}

Ten fetuses had their urinary tracts drained and were delivered after the 28th week of pregnancy. Four died within 48 hours of delivery from respiratory difficulties caused by pulmonary hypoplasia (tables I and II). All six survivors had reasonable renal function, though one required nephrectomy ${ }^{12}$ and one had mild renal dysplasia. ${ }^{23}$ Of the four delivered at this hospital without intervention one died aged 1 month and three are alive, but one of these has severe pulmonary hypoplasia and at the age of 18 weeks still required assisted ventilation. One child delivered elsewhere at 32 weeks without the urinary obstruction being relieved was alive 18 months later but in chronic renal failure. ${ }^{18}$

Data on the birth weight of affected infants are difficult to interpret because the contents of the dilated urinary tract form a substantial proportion of the child's weight. One fetus of 16 weeks was estimated to have $250 \mathrm{ml}$ urine in his dilated bladder, ${ }^{12}$ and $1000 \mathrm{ml}$ was drained from another at 27 weeks when body weight is normally about $1 \mathrm{~kg} .{ }^{24}$

Growth may be impaired in survivors: one boy in whom a catheter was inserted in utero for two weeks to relieve obstruction of the urinary tract was delivered in March $1979 .{ }^{12}$ His birth weight was below the first centile, and he has continued to grow along this centile despite having one normally functioning kidney and no infection or other problems (figure). At the age of 45 months he was the same height and weight as his brother who was born 15 months after him. Though his height and weight are low his renal function is adequate, and he is passing other developmental milestones normally.

In the eight viable fetuses whose urinary tracts were drained, survival and health were not consistently related to the gestational age at which the obstruction was first detected (whether or not the urinary tract was known to be normal before that), or to the age at which the catheter was inserted, or to the duration of catherisation. Severe oligo-hydramnios did not reflect the chances of survival, but it may be advantageous for the obstruction to be part of the prune belly syndrome with its lax abdominal wall. Too few children have been followed up for more than a few months for their development to be reviewed critically. The one followed up for four years was born small and has continued small, and this sugegsts that others born light may also have growth retardation whe ilbeing mentally normal. Studies of 10 year survivors whose obstruction was relieved soon after delivery have shown that severe renal failure may take several years to appear. ${ }^{26}$ Assessment must also include the stresses within a family produced by a child who is not wholly normal, and which would be increased were he to require dialysis or renal transplantation.

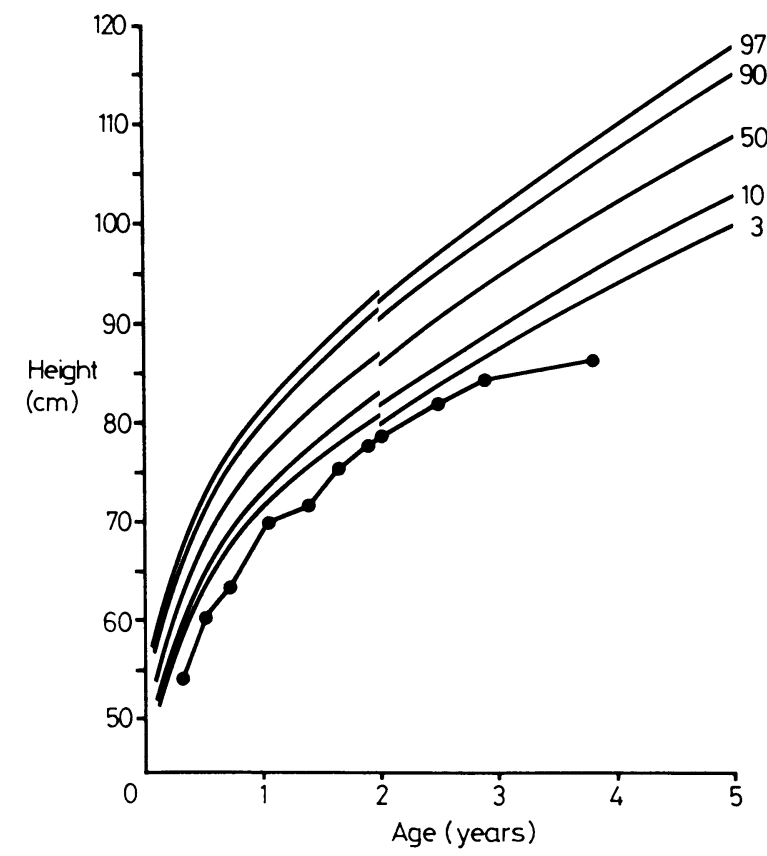

Increase in height over four years by the boy whose height was below the first centile after catheterisation for two weeks of his obstructed urinary tract. The centile values are those of Tanner et al, 1966. ${ }^{29}$

\section{Balance of risks}

The risks of intervention are small for both mother and fetus, but can they be justified? Without catheterisation the fetal condition seems likely to deteriorate, whereas in some of those in whom a catheter was inserted pulmonary maturation undoubtedly occurred, and there is a real possibility of arrest or prevention of renal maldevelopment. The treatment may do good and does no harm. Before treatment is started, however, the fetal condition should be fully diagnosed-a process that requires detailed investigations and so induces a feeling of commitment in both parents and physician. A decision to withhold treatment may then prove difficult if the fetus is found to have an irremediable defect. Advice and counselling must depend on the scanty information available, but further experience when parents do request intervention will help to clarify indications and contraindications, not only from review of neonatal morbidity and mortality but also by following the survivors' health as they progress through childhood. The ethical and legal problems associated with the treatment of the fetus are still being debated ${ }^{2728}$ : both they and medical expertise have to keep pace with new possibilities in the treatment of anomalies discovered before birth which are offered by technological advances.

Fetal diagnosis by ultrasound is dependent on the skill of the 
ultrasonologist: Dr H B Meire and Miss P Farrant gave both their skill and enthusiasm in the diagnosis and management of the cases discovered at Northwick Park, and I thank them for their part in the experience reviewed here.

\section{References}

${ }^{1}$ Heinonen OP, Slone D, Shapiro S. Birth defects and drugs in pregnancy. Littleton, Massachusetts: Publishing Sciences Group Inc, 1977.

${ }^{2}$ Kullendorff CM, Larsson LT, Jorgensen C. The advantage of antenatal diagnosis of intestinal and urinary tract malformations. $\mathrm{Br} \mathcal{F}$ Obstet Gynaecol (in press).

${ }^{3}$ Farrant PH. Early ultrasound diagnosis of fetal bladder neck obstruction. Br F Radiol 1980;53:506-8.

${ }^{4}$ Meschia G, Cotter JR, Breathnach CS, Barron DH. The haemoglobin oxygen carbon dioxide and hydrogen ion concentrations in the umbilical bloods of sheep and goats as sampled via indwelling plastic catheters. Qf Exp Physiol 1965;50:185-95.

${ }^{5}$ Mellor DJ, Slater JS. Daily changes in fetal urine and relationships with amniotic and allantoic fluid and maternal plasma during the last two months of pregnancy in conscious unstressed ewes with chronically implanted catheters. F Physiol (Lond) 1972;227:503-25.

6 Potter EL, Craig JM. Pathology of the fetus and infant. Chicago: Year Book Medical Publishers Inc, 1976.

'Pagon RA, Smith DW, Shepard TH. Urethral obstruction malformation complex: a cause of abdominal muscle deficiency and the 'prune belly.' f Pediatr 1979;94:900-6.

8 Smythe AR. Ultrasonic detection of fetal ascites and bladder dilatation with resulting prune belly. $\mathcal{F}$ Pediatr $1981 ; 98: 978-80$.

${ }^{9}$ Thorburn GD. The role of the thyroid gland and kidneys in fetal growth. Size at birth, Ciba Foundation Symposium 27. Amsterdam: Elsevier Excerpta Medica, North Holland, 1974.

10 Betts PR, White RHR. Growth potential and skeletal maturity in children with chronic renal insufficiency. Nephron 1976;16:325-32.

11 Krueger RP, Hardy BE, Churchill BM. Growth in boys with posterior urethral valves. Urol Clin North Am 1980;7:265-72.

${ }_{12} \mathrm{McF}$ adyen IR, Wigglesworth JS, Dillon MJ. Fetal urinary tract obstruction: is active intervention before delivery indicated? $\mathrm{Br} \mathcal{F}$ Obstet Gynaecol 1983;90:342-9.

${ }^{13}$ Hecht F. In : Bergsma D, ed. Birth defects compendium. 2nd ed. London: MacMillan Press Ltd, 1979:201.

${ }^{14}$ Albrecht RC, Cefalo RC, Lewis PE, Smith JP. Fetal growth after premature rupture of the membranes. Am $\mathcal{F}$ Obstet Gynecol 1977;127: 869-70.
15 Wigglesworth JS, Desai R. Effects on lung growth of cervical cord section in the rabbit fetus. Early Hum Dev 1979;3:51-65.

${ }^{16}$ Blackburn WR, Logsdon P, Alexander JA. Congenital diaphragmatic hernia: studies of lung composition and structure. Am Rev Respir Dis $1977 ; 115$, suppl :275.

17 Wigglesworth JS, Desai R, Guerrini P. Fetal lung hypoplasia: biochemical and structural variations and their possible significance. Arch Dis Child $1981 ; 56: 606-15$.

${ }^{18}$ Harrison MR, Filly RA, Parer JT, Faer MJ, Jacobson JB, de Lorimier AA. Management of the fetus with a urinary tract malformation. $\mathcal{F} A M A$ $1981 ; 246: 635-9$.

19 Manning FA, Harman CR, Lange IR, Brown R, Dector A, MacDonald N. Antepartum chronic fetal vesicoamniotic shunts for obstructive uropathy: a report of two cases. Am 7 Obstet Gynecol 1983;145:819-22.

${ }^{20}$ Berkowitz RL, Glickman MG, Walker Smith GJ, et al. Fetal urinary tract obstruction: what is the role of surgical intervention in uterc? Am $\mathcal{F}$ Obstet Gynecol 1982;144:367-75.

21 Vintzileos AM, Nochimson DJ, Walzak MP, Conrad FU, Lillo NL. Unilateral fetal hydronephrosis: successful in utero surgical management. Am F Obstet Gynecol 1983;145:885-6.

22 Schapps JP, Thoumsin H, Lambotte R. Intrauterine unilateral nephrostomy. Am $\mathcal{F}$ Obstet Gynecol 1983;146:105-6.

${ }^{23}$ Golbus MS, Harrison MR, Filly RA, Callen PW, Katz M. In utero treatment of urinary tract obstruction. Am $\mathcal{F}$ Obstet Gynecol 1982;142: 383-8.

24 Gadziala NA, Kawada CY, Doherty FJ, Koza DJ. Intrauterine decompression of megalocystis during the second trimester of pregnancy. Am $\mathcal{F}$ Obstet Gynecol 1982;144:355-6.

${ }^{25}$ Harrison MR, Golbus MS, Filly RA, Callen PW, Katz M, de Lorinier AA. Fetal surgery for congenital hydronephrosis. N Engl f Med $1982 ; 306$ : 591-3.

26 Warshaw BL, Edelbrook $\mathrm{HH}$, Ehenger RB, et al. Progression to end stage renal disease in children with obstructive uropathy. $\mathcal{f}$ Pediatr 1982;100:183-7.

${ }^{27}$ McFadyen IR. Fetal survival-who decides. $\mathcal{f}$ Med Ethics 1978;4:30-1.

28 Elias S, Annas GJ. Perspectives on fetal surgery. Am $\mathcal{F}$ Obstet Gynecol $1983 ; 145: 807-12$.

29 Tanner JM, Whitehouse RH, Takaishi $M$. Standards from birth of maturity for height, weight, height velocity and weight velocity: British children 1965. Arch Dis Child 1966;41:454-71; 613-35.

30 Thomson AM, Billewicz WZ, Hytten FE. The assessment of fetal growth. Fournal of Obstetrics and Gynaecology of the British Commonwealth 1968;75:903-16.

(Accepted 5 October 1983)

\section{Indian reflections: French with tears}

My French was far from satisfactory when I joined the Clinique of the Hôpital des Enfants Malades in Paris as an "assistant étranger." No accommodation was available at the new university lodgings called the "Cité Universitaire" briefly known as the "Cité." It had many international houses, including the Collège Franco-Britannique which was essentially a British house. Naturally I was anxious to get a room there as English was the only foreign language I knew at that time. But I had no luck. So I had no alternative but to look for private lodgings. From the welfare bureau of the university I had obtained a list of addresses of private lodgings and I set out in the quest of a suitable abode.

At last I found one in Rue Gustav le bon, not far from the "Cité." I was much relieved because I could have meals at the "Cité" cafeteria. In comparison with the Paris restaurants, food at the cafeteria, though simple, was wholesome and cheap.

I pressed the doorbell of the apartment. A lady past middle age with a sad face and in a black dress opened the door. Obviously she was in mourning. She looked at me inquiringly. I was nonplussed for a moment. "Madame Duval ?" I inquired, "Oui Monsieur," she answered. I introduced myself and told her the object of my visit. "Monsieur, mon mari est mort," she said. That explained her black dress. Her husband had died of a heart attack a few days ago, I learnt. I had not at all expected to find myself in such a situation so soon after arriving in Paris. I faltered out a few words of apology for disturbing her and expressed my sympathy. I realised I had arrived at an inopportune time and was about to leave. But she paused for a moment, then let me in and showed me the room she had proposed to let. The room had the bare essential furniture with an adjoining toilet. She told me I could have a wash but no bath there and definitely could not bring any "jeune fille" to the room. I accepted her terms, thanked her, and left to bring my kit.

I had some knowledge of English landladies, but I had no idea of what their counterparts on this side of the Channel would be. Bed and breakfast with or without dinner was the usual arrangement in digs in England. And the luxury or the ritual of a bath was allowed once a week, preferably at night, for which advance notice had to be given to the landlady. Here in Paris I had to be content with a room and a wash when necessary. By my standards it was "la vie de Bohème" which the artists led in "Quartier Latin," about whom Somerset Maugham has written in his novels.

It did not take me long to settle down. I used to walk across to the "Cité" cafeteria in the morning for my "petit déjeuner," which consisted usually of croissant and café au lait or chocolate, and occasionally I had jambon. I thoroughly enjoyed my French breakfast, which was a change from kippers or fried eggs and bacon. I soon made a few acquaintances in the "Cité" and managed to have my weekly bath there.

Madame Duval lived alone in the apartment. Her daughter, accompanied by her son Pierre, used to visit her at weekends which broke the monotony of her solitary existence. She was grief stricken and spoke very little. Her only social overture would be to ask me occasionally if I would care for some café when I happened to be in. So I was surprised when, one morning as I was preparing to leave for the clinic, she urgently summoned me to see her grandson Pierre, who was ill. I found the boy had measles. I told her so and reassured her. "Rougeole vraiment ?" she asked, not looking very convinced. She probably thought that I must have imported some mysterious infection from the Orient.

The same evening as I returned from the "Clinique" Madame Duval greeted me at the door with a broad smile. "Vous êtes un bon diagnosticien, Monsieur," she said. It transpired she had taken a second opinion to confirm my diagnosis, so the compliment she paid failed to flatter me. Apparently she had taken me for a novice.$S$ K MAJUMDAR, director, HHRD Medical Trust, Jodhpur, Rajasthan, India. 